\title{
Species of Botryosphaeriaceae associated on mango in Brazil
}

\author{
Valéria Sandra de Oliveira Costa • Sami Jorge Michereff • \\ Ricardo Brainer Martins • Carlos Alberto Tuão Gava • \\ Eduardo Seiti Gomide Mizubuti • Marcos Paz Saraiva Câmara
}

Accepted: 19 April 2010 / Published online: 14 May 2010

(C) KNPV 2010

\begin{abstract}
The aim of the present study was to assess diversity in the Botryosphaeriaceae on trees and fruit of mango (Mangifera indica L.) in a semi-arid region in northeastern Brazil in which most exported fruit in the country are produced. Using morphological characteristics and DNA sequence data (ITS-1, ITS-2 and 5.8S rDNA) we confirmed the presence of Lasiodiplodia theobromae in the region, and for the first time report Fusicoccum aesculi and Neofusicoccum parvum. $L$. theobromae was prevalent in the Assú Valley and $F$. aesculi and $N$. parvum were in the São Francisco Valley. In fruit inoculations, $L$. theobromae and $N$. parvum were more virulent than $F$. aesculi.
\end{abstract}

Keywords Botryosphaeria dothidea $\cdot$ Fusicoccum aesculi $\cdot$ Neofusicoccum parvum $\cdot$ Lasiodiplodia theobromae Phylogeny

V. S. de Oliveira Costa $\cdot$ S. J. Michereff - R. B. Martins •

M. P. S. Câmara $(\bowtie)$

Departamento de Agronomia, Universidade Federal Rural de Pernambuco,

52171-900 Recife, Brazil

e-mail: mcamara@depa.ufrpe.br

C. A. T. Gava

Embrapa Semi-Árido,

56302-970 Petrolina, Brazil

E. S. G. Mizubuti

Departamento de Fitopatologia, Universidade Federal de

Viçosa,

36570-000 Viçosa, Brazil

\section{Introduction}

Mango (Mangifera indica L.) is an economically important fruit crop in the tropics. In Brazil, the main areas of cultivation are in the semi-arid northeast, in which the São Francisco and Assú Valleys are most important (Fig. 1). Mangos produced in these areas are mainly for export, primarily to the United States, Japan and countries of the European Union. In 2008, Brazil exported mangos worth approximately US\$ 90 million. This crop also plays an important social role, generating over 25,000 direct and 75,000 indirect jobs in the São Franscico Valley alone (Souza et al. 2002).

Species of the Botryosphaeriaceae family are associated with several host plants, and can act as pathogens, primary or secondary, and endophytes that under stress conditions of the host plant can become pathogenic or saprophytic (Crous et al. 2006; Denman et al. 2000). In Brazil, as in other countries (Javier-Alva et al. 2009; Al Adawi et al. 2003; Khanzada et al. 2005), species of the family have become increasingly important problems for mango producers, and are often associated with plants and fruits showing tip dieback and stem-end rot symptoms (Freire et al. 2004; Tavares 2002; Tavares et al. 1991). Both diseases are caused by a complex of fungi, but those in the Botryosphaeriaceae are most important (Javier-Alva et al. 2009; Al Adawi et al. 2003; Slippers et al. 2005). Tip dieback 
Fig. 1 Collection sites of Botryosphaeriaceae isolates in the São Francisco Valley and Assú Valley located in the states of Bahia (BA), Pernambuco (PE) and Rio Grande do Norte $(\mathrm{RN})$, Brazil. Circles represent association frequency of each species with samples (branches, leaves, panicles and fruit) exhibiting symptoms of dieback/peduncle rot in each region sampled and $n$ is the number of isolates analyzed in each region

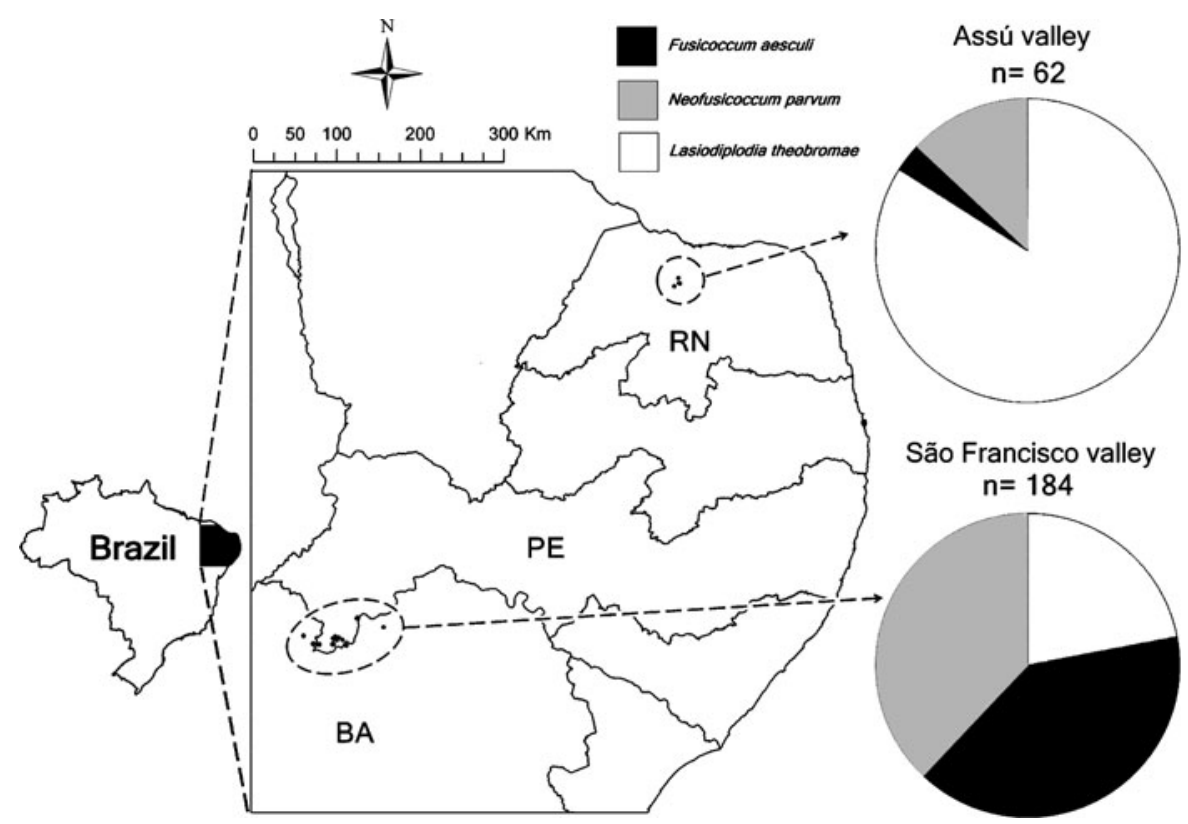

is characterized by a progressive drying out of the branches. The disease begins at the tip of the branches, advances towards the trunk and, in more severe cases, can result in the death of the plant (Ribeiro 1997). Leaves and inflorescences may also be affected (Ribeiro 1997). Stem-end rot of fruit may develop in the field, as well as after harvest during storage or shipment. Stem-end rot symptoms are dark spots with defined edges on the epidermis of the fruit that emanate from the stem end; the affected areas may split open, exposing the pulp, which becomes soft and watery (Ribeiro 1997).

The first report of a species in the Botryosphaeriaceae pathogenic to mango in Brazil occurred in 1947 (Batista 1947). In this study the author investigated the etiology of the disease known as "Seca da Mangueira", caused by Ceratocystis fimbriata (Ribeiro 1997). At that time, Batista (1947) isolated and confirmed the pathogenicity of a member of the Botryosphaeriaceae family which he called Diplodia recifensis Bat. Given the distinct characteristics of reproductive structures, especially with respect to pigmentation of conidia, it is unlikely that there has been confusion in species identification by Batista.

Nearly 50 years later, large-scale death of mango trees was reported in the São Francisco Valley (Tavares et al. 1991) and, since then, the intensity of the disease has increased, leading in some cases to the complete loss of production and elimination of entire orchards (Nogueira et al. 2001; Tavares 2002; Tavares et al. 1991). In Brazil, both diseases are attributed to the fungus Lasiodiplodia theobromae (Pat.) Griff \& Maubl. (Freire et al. 2004; Tavares 2002; Tavares et al. 1991). However, other species of Botryosphaeriaceae, such as Neofusicoccum parvum (Pennycook \& Samuels) Crous, Slippers \& A.J.L. Phillips, Neofusicoccum mangiferae (Pennycook \& Samuels) Crous, Slippers \& A.J.L. Phillips and Botryosphaeria dothidea (Moug.) Ces. \& De Not. affect mango in other countries (Ramos et al. 1997; Khanzada et al. 2004; Ramos et al. 1991; Ploetz et al. 1996). The latter species have not been reported as pathogens of mango in Brazil but $F$. aesculi has been associated with other plants in northeastern Brazil (Mendes et al. 1998).

The morphological identification of species in the Botryosphaeriaceae is based primarily on characteristics of the anamorphs, which are normally found in the field and are easily cultured in vitro (Crous et al. 2006; Denman et al. 2000). These criteria include the type of conidiogenesis; conidial characters such as pigmentation, number of septa, wall thickness and texture, ornamentation and dimensions; presence of microconidia; and culture characteristics, such as colony colour (Pereira et al. 2006; Crous et al. 2006; Denman et al. 2000). The teleomorphs are uncommon 
in nature, rare in vitro (Denman et al. 2000; Crous et al. 2006), and have a limited number of attributes for identifying species (Crous et al. 2006; Denman et al. 2000).

Since morphological characters sometimes overlap between species and can be variable (Slippers et al. 2005; Ramos et al. 1991, 1997), molecular tools have been utilized to better elucidate the taxonomy and phylogeny of the Botryosphaeria group (Crous et al. 2006; Denman et al. 2000; Ma et al. 2001; Ma and Michailides 2002; Niekerk et al. 2004; Slippers et al. 2004). For example, based on morphological and phylogenetic analyses conducted with sequences from the ITS region of the rDNA (ITS1, 5.8S and ITS2), Denman et al. (2000) suggested that all Botryosphaeria anamorphs should be reduced to only two genera: Fusicoccum (hyaline conidia) and Diplodia (pigmented conidia). After studying sequences from the $28 \mathrm{~S}$ region of the rDNA, Crous et al. (2006) suggested that the genus Botryosphaeria should be restricted to just $B$. dothidea (anamorph: Fusicoccum aesculi) and $B$. corticis (Demaree \& Wilcox) Arx \& E. Müll, and proposed that the genus Neofusicoccum Crous, Slippers \& A.J.L. Phillips be used to accommodate anamorphs in Fusicoccum and Diplodia. No teleomorph name has been proposed for species of Botryosphaeriaceae with anamorphs in Lasiodiplodia, Diplodia, Macrophomina Petr., Pseudofusicoccum Mohali, Slippers \& M.J. Wingf., Neoscytalidium Crous \& Slippers or Dothiorella (Crous et al. 2006).

Considering the current problem of tip dieback and stem-end rot in Brazil and the importance of developing management programs that are based on the pathogens that occur in the field, morphological and molecular characteristics were used to identify species in the Botryosphaeriaceae that were associated with tip dieback and stem-end rot of mango in the semi-arid region of northeastern Brazil.

\section{Material and methods}

Sampling and isolation

During 2006 and 2007, isolates in the Botryosphaeriaceae were obtained from 18 orchards (20 samples per orchard) located in the two major mango-producing regions in northeastern Brazil: São Francisco Valley and Assú Valley (Fig. 1).
Samples of leaves and panicles with dieback symptoms and fruit with stem-end rot were recovered from the cultivars Tommy Atkins, Kent, Keitt, Van Dyke, Haden, Espada and Palmer. Plant tissue was surface-disinfested in $70 \%$ ethanol for $30 \mathrm{~s}$ and $1 \%$ $\mathrm{NaOCl}$ for $1 \mathrm{~min}$, rinsed in sterile distilled water for $30 \mathrm{~s}$, and dried before small pieces of tissue were taken from the margin between necrotic and apparently healthy tissue and plated onto potato dextrose agar (ACUMEDIA). Hyphae growing out from the tissue pieces were subcultured onto fresh PDA. For the experiments, a hyphal tip isolate was obtained for each isolate. Thus, a total of 246 hyphal tip isolates was used. Cultures of the isolates are maintained in the Professora Maria Menezes Phytopathogenic Fungi culture collection of the Universidade Federal Rural de Pernambuco, Recife, Pernambuco, Brazil.

Morphological characterization

Morphometric characteristics of the conidia (dimensions, shape, colour, presence of septa and longitudinal striations) (Slippers et al. 2004, 2005) were recorded. Each isolate was cultured on sterile pine needles on the surface of water agar (WA: Agar, $20 \mathrm{~g} \mathrm{l}^{-1}$ ). The dishes were exposed to black light with a 12 -h photoperiod at $20-25^{\circ} \mathrm{C}$ (Slippers et al. 2004). On a weekly basis, the dishes were examined for the formation of pycnidia on the needles. When pycnidia were formed, morphological characteristics of 50 conidia per isolate were recorded. Length and width of the conidia were measured using an Olympus BX41 microscope using the Images Plus 2.0 imaging software program (Motic China Group Co., Ltd).

DNA extraction, amplification of the ITS region and phylogenetic analysis

Fourteen isolates that represented different regions, hosts and fungal species were selected for molecular analyses (Table 1). Extraction of total genomic DNA was performed based on the CTAB protocol (Murray and Thompson 1980). The ITS 4 and ITS 5 primers (White et al. 1990) were used for the amplification of the ITS region (including the $5.8 \mathrm{~S}$ gene) of the rDNA. PCRs were conducted in a thermalcycler (PTC 100; M. J. Research Company) under the following conditions: initial preheating at $95^{\circ} \mathrm{C}$ for $120 \mathrm{~s}$, followed by 35 cycles of denatur- 
Table 1 Botryosphaeria isolates used in the phylogeny study

\begin{tabular}{|c|c|c|c|c|c|}
\hline Isolate & Identity & Host & Origin & Collector & GenBank ${ }^{\mathrm{a}}$ ITS \\
\hline CMM1472 & Lasiodiplodia theobromae & Mangifera indica & Brazil & V.S.O. Costa & EU915208 \\
\hline CMM1476 & L. theobromae & M. indica & Brazil & V.S.O. Costa & EU938326 \\
\hline CMM1485 & L. theobromae & M. indica & Brazil & V.S.O. Costa & EU938327 \\
\hline CMM1496 & L. theobromae & M. indica & Brazil & V.S.O. Costa & EU938328 \\
\hline CMM1510 & L. theobromae & M. indica & Brazil & V.S.O. Costa & EU938329 \\
\hline CMM1516 & L. theobromae & M. indica & Brazil & V.S.O. Costa & EU938330 \\
\hline CMM1543 & L. theobromae & M. indica & Brazil & V.S.O. Costa & EU938331 \\
\hline CMM1548 & L. theobromae & M. indica & Brazil & V.S.O. Costa & EU938332 \\
\hline CMW10130 & L. theobromae & Vitex donniana & Uganda & J. Roux & $A Y 236951$ \\
\hline CMW9074 & L. theobromae & Pinus sp. & Mexico & T. Burgess & AY236952 \\
\hline CMM1317 & Neofusicoccum parvum & M. indica & Brazil & V.S.O. Costa & EU938333 \\
\hline CMM1276 & N. parvum & M. indica & Brazil & V.S.O. Costa & EU938334 \\
\hline CMM1271 & N. parvum & M. indica & Brazil & V.S.O. Costa & EU938335 \\
\hline CMW7025 & N. parvum & M. indica & Australia & G.I. Johnson & AY615181 \\
\hline CMW7026 & N. parvum & M. indica & Australia & G.I. Johnson & AY615182 \\
\hline CMW7799 & N. parvum & Persea americana & Australia & K.G. Pegg & AY615184 \\
\hline CMW9078 & N. parvum & Actinidia deliciosa & New Zealand & S.R. Pennycook & $A Y 236940$ \\
\hline CMW9081 & N. parvum & Populus nigra & New Zealand & G.J. Samuels & $A Y 236943$ \\
\hline CMM1302 & Fusicoccum aesculi & M. indica & Brazil & V.S.O. Costa & EU938336 \\
\hline CMM1319 & F. aesculi & M. indica & Brazil & V.S.O. Costa & EU938337 \\
\hline CMM1327 & F. aesculi & M. indica & Brazil & V.S.O. Costa & EU938338 \\
\hline CMW7780 & F. aesculi & Fraxinus excelsior & Switzerland & B. Slippers & $A Y 236947$ \\
\hline CMW8000 & F. aesculi & Prunus sp. & Switzerland & B. Slippers & $A Y 236949$ \\
\hline CMW7020 & F. aesculi & M. indica & Australia & G.I. Johnson & AY615191 \\
\hline CMW7027 & F. aesculi & M. indica & Australia & G.I. Johnson & AY615192 \\
\hline CMW7803 & F. aesculi & M. indica & Australia & G.I. Johnson & AY615193 \\
\hline CMW7024 & Neofusicoccum mangiferum & M. indica & Australia & G.I. Johnson & AY615185 \\
\hline CMW7797 & N. mangiferum & M. indica & Australia & G.I. Johnson & AY615186 \\
\hline CMW7801 & N. mangiferum & M. indica & Australia & G.I. Johnson & AY615187 \\
\hline CMW7063 & Bionectria sp. & Taxus baccata & Netherlands & H.A. van der Aa & $A Y 236956$ \\
\hline
\end{tabular}

${ }^{\text {a }}$ Sequence numbers in italics were obtained from the GenBank public database. All others were obtained in the study

ation at $94^{\circ} \mathrm{C}$ for $60 \mathrm{~s}$, annealing at $60^{\circ} \mathrm{C}$ for $90 \mathrm{~s}$ and extension at $72^{\circ} \mathrm{C}$ for $120 \mathrm{~s}$, with a final extension step at $72^{\circ} \mathrm{C}$ for $300 \mathrm{~s}$. PCR products were separated electrophoretically in $0.8 \%$ agarose gels and $0.5 \mathrm{X}$ Tris-boric acid-EDTA(TBE) buffer, stained with ethidium bromide $\left(0.08 \mu \mathrm{g} \mathrm{ml}^{-1}\right)$ for $10 \mathrm{~min}$, and photographed. PCR products were purified with the High Pure PCR Product Purification Kit (Roche), following the manufacturer's recommendations. $\mathrm{Pu}$ rified products were sequenced in the sense and antisense directions (MegaBACE sequencer) at the
Genomics Laboratory of the Instituto de Biotecnologia Aplicada à Agricultura-BIOAGRO of the Universidade Federal de Viçosa (Brazil).

Sequences were initially aligned using Clustal X (Thompson et al. 1994), and adjusted manually when necessary. Sequences from other species in the Botryosphaeriaceae that have been reported as pathogens of mango and other hosts were recovered from GenBank and included in the analyses (Table 1). Sequences that were generated in the present study were trimmed to the length of those in 
GenBank prior to analyses. Maximum Parsimony (MP) and Maximum Likelihood (ML) phylogenetic analyses were conducted with the PAUP (v.4.0b10; Sinauer Associates) and GARLI (Zwickl 2006) programs for Macintosh, respectively. In both analyses, Bionectria sp. was used as outgroup, as reported elsewhere (Slippers et al. 2005). Heuristic searches for MP were performed with the addition of 100 random repetitions and the rearrangement of the branches was obtained using the tree-bisectionreconnection (TBR) method, saving a maximum of 10,000 trees; all characters were non-rooted, with equal weights, and the gaps were treated as missing data. Branches with a length of zero were eliminated and all equally parsimonious trees were saved. For the ML analyses, the best evolution model for each locus was obtained using the Modeltest v.3.06 program (Posada and Crandall 1998).

Clade support was calculated with the nonparametric bootstrap method and 1,000 replicates for MP and 100 replicates for ML. For ML, tree length, consistency index $(\mathrm{CI})$ and retention index (RI) were also obtained. For the ML tree, the best evolution model was also obtained. The resulting trees were printed in PAUP. ITS sequences from the present study were deposited in GenBank (Table 1).

Pathogenicity, virulence and host associations

Pathogenicity was assessed for 246 isolates that were evaluated morphometrically. 'Tommy Atkins' fruit were washed with soap and water, surface disinfested by immersion in $1.5 \% \mathrm{NaOCl}$ for $5 \mathrm{~min}$ and rinsed in distilled water. Each fruit was then perforated at four equidistant points to a depth of $3 \mathrm{~mm}$ with disinfested pins. Fruit were inoculated by placing over each perforation a 5-mm-diameter PDA disk taken from the edge of 7-day old colonies of a given isolate, and noncolonized PDA disks were used in the control treatment. A completely randomized design was used, wherein isolates were replicated on two fruit and the four inoculation points were repeated observations. Treated fruit were incubated at $25^{\circ} \mathrm{C}$ with a 12 $\mathrm{h}$ photoperiod and near $100 \%$ relative humidity. After $72 \mathrm{~h}$, the presence or absence of symptoms was visually inspected. In the control treatment, lesions were restricted to the injured area at the time of deposition of PDA discs. Isolates were considered pathogenic when the injured area advanced beyond the 5-mm diameter initial injury.

The virulence of 14 isolates that were used in the phylogenetic analyses was evaluated as above, except that treatments were replicated four times. Mean diameters for treatments were separated with the non-parametric Mann-Whitney test $(P=0.05)$ and the SAS 8.0 program (SAS Institute Inc.). Chisquare analyses were used to assess relationships between cultivars and organs, species and regions, and species and organs.

\section{Results}

Isolates and morphological characterization

A total of 246 hyphal tip isolates was evaluated morphometrically. Pycnidia and conidia developed on pine needles after 1-4 weeks. The isolates were separated into three groups and identified as: Fusicoccum aesculi (B. dothidea) (75 isolates), characterized by hyaline, thin-walled, spindleshaped conidia with no septa, measuring $22.1 \times$ $5.1 \mu \mathrm{m}$ [length/width ratio $(\mathrm{L} / \mathrm{W})=4.3]$ (Fig. 2a, Table 2); N. parvum (79 isolates), which differs from $F$. aesculi only in the conidial dimensions, $15.9 \times$ $5.2 \mu \mathrm{m}(\mathrm{L} / \mathrm{W}=3.3)$ (Fig. 2b, Table 2); and $L$. theobromae (92 isolates), characterized by brown, thick-walled mature conidia, with longitudinal striations, measuring $23.9 \times 13.5 \mu \mathrm{m}(\mathrm{L} / \mathrm{W}=1.7)$ (Fig. $2 \mathrm{c}$, Table 2). No teleomorph was observed for any isolate during the study.

The three species were found in both study regions, but their relative prevalence differed in each. In the São Francisco Valley, F. aesculi and N. parvum were more prevalent than $L$. theobromae, whereas $L$. theobromae was the predominant species in the Assú Valley $(P=0.05)$ (Figs. 1 and $3 a)$. Species recovery also differed on the different mango cultivars $(P=0.05)$ : only $F$. aesculi was associated with all that were examined; $N$. parvum was isolated from Tommy Atkins, Van Dyke, Haden, Kent and Keitt; and L. theobromae was only isolated from Tommy Atkins (Fig. 3c). Plant organ also had a significant impact: $F$. aesculi was the only species that was found on all organs, whereas $N$. parvum was never isolated from panicles and L. theobromae was only isolated from branches and fruit $(P=0.05$; 

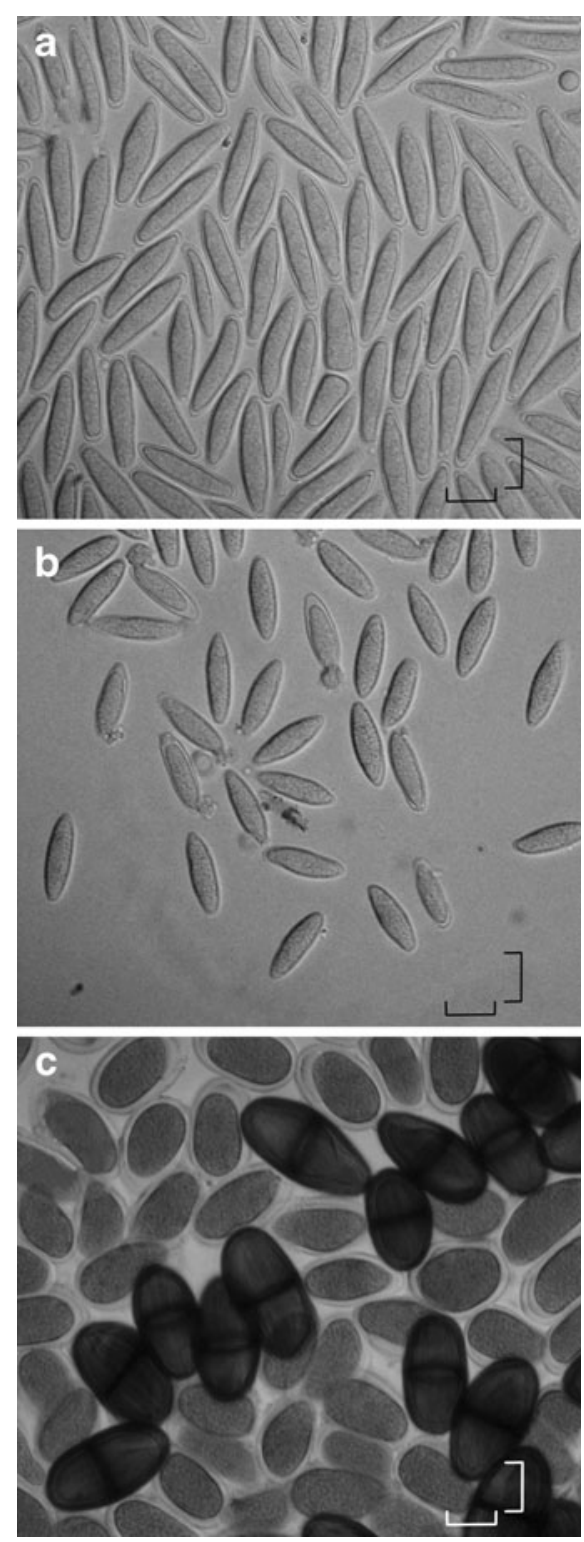

Fig. 2 Morphology of conidia from species of Botryosphaeriaceae associated with mango trees in northeastern Brazil. a Fusicoccum aesculi (isolate CMM1327): conidia hyaline, thin wall, spindleshaped, with no septa; b Neofusicoccum parvum (CMM1317): conidia hyaline, thin wall, spindle-shaped to ellipsoid, with no septa; c Lasiodiplodia theobromae (CMM1485): mature conidia mature, thick-walled, dark-brown colouration, longitudinal stripes, young conidia thick-walled and hyaline. Photos taken with $\times 100$ magnification (immersion oil) from fructification bodies (pycnidia) formed on pine needles in agar-agar medium. Bar $=10 \mu \mathrm{m}$

Fig. 3b). Although species in the Botryosphaeriaceae predominated in dieback and stem-end rot isolations, $38.5 \%$ of the samples yielded other fungi, including Pestalotiopsis sp., Cladosporium sp., Alternaria sp.,
Phomopsis sp., Nigrospora sp., Curvularia sp., Colletotrichum sp., Chaetomium sp., Chaetophoma sp., Stemphylium sp. and Bipolaris sp.

Phylogenetic analysis of isolates in the Botryosphaeriaceae

A matrix of 30 taxa and 598 characters was constructed. A total of 182 characters was variable and 63 were parsimony informative. For the MP analysis, heuristic searches found 10,000 equally parsimonious trees (tree length $=228, \mathrm{CI}=0.904$, RI $=0.957$; Fig. 4). For the ML analysis, the best nucleotide substitution model using both the Akaike test and hierarchical likelihood was TIMef $+\mathrm{G}$; a single tree with score -1699.59 was obtained. Results did not differ with the different analytical methods.

The phylogenetic tree inferred from the ITS region revealed four species-specific clades with a bootstrap support greater than $91 \%$ and $64 \%$ for the MP and ML analyses, respectively. Clade I was composed of $N$. mangiferum, Clade II of $L$. theobromae, Clade III of F. Aesculi/B. dothidea, and Clade IV of $N$. parvum (Fig. 4). On the ML tree, ML/ MP bootstrap values are listed at nodes; isolates collected in the present study are distributed among Clades II, III and IV (Fig. 4).

The L. theobromae isolates formed a strongly supported clade with bootstrap values of $100 \%$ (Fig. 4). The Brazilian isolates of L. theobromae were similar to, and grouped with, isolates from Uganda and Mexico, even though the latter isolates were obtained from Vitex donniana and Pinus sp. (Clade II). Isolates of $F$. aesculi grouped with those from Australia that were obtained from mango, as well as Fraxinus excelsior and Prunus sp. (Clade III), and those of $N$. parvum also grouped with those from an Australian mango, as well as other hosts (Clade IV) (Fig. 4; Table 1). Within a given species, minor differences were observed among the Brazilian isolates: those of $L$. theobromae differed at four bp, F. aesculi at six bp, and N. parvum at two bp. The identity of the ITS sequences of the Brazilian isolates with those deposited in Gen Bank ranged from $98 \%$ to $100 \%, 97 \%$ to $100 \%$ and $98 \%$ to $100 \%$ for $L$. theobromae, F. aesculi and $N$. parvum, respectively. The MP and ML analyses produced nearly identical topologies (tree not 
Table 2 Dimensions of conidia of select species of Botryosphaeriaceae

${ }^{\mathrm{a}}$ Minimal and maximal dimensions between parentheses; number of conidia measured between brackets ${ }^{\mathrm{b}} \mathrm{L} / \mathrm{W}=$ length/width

\begin{tabular}{llll}
\hline Species & Conidium size $(\mu \mathrm{m})^{\mathrm{a}}$ & L/W & Data source \\
\hline Fusicoccum aesculi & $(20) 24.77(30) \times(4) 4.9(6)[102]$ & 5 & Slippers et al.. 2004 \\
& $(18.8) 23(30.4) \times(4.5) 5.1(7)[>50]$ & 4.5 & Slippers et al. 2005 \\
& $(16) 22.1(27) \times(3) 6(5.1)[50]$ & 4.3 & Present study \\
Neofusicoccum parvum & $(14.7) 19(25.5) \times(4.5) 5.2(7)[>50]$ & 3.7 & Slippers et al. 2005 \\
& $(13) 15.9(22) \times(4) 5.2(7)[50]$ & 3.3 & Present study \\
Lasiodiplodia theobromae & $(17) 22.6(33) \times(10) 12.2(15)[30-40]$ & 1.9 & Burgess et al. 2006 \\
& $(18) 23.9(28) \times(11) 13.5(16)[50]$ & 1.7 & Present study \\
N. mangiferum & $(11-) 13.6(-17.3) \times(5) 5.4(6.6)[54]$ & 2.5 & Slippers et al. 2005 \\
\hline
\end{tabular}

Fusicoccum aesculi

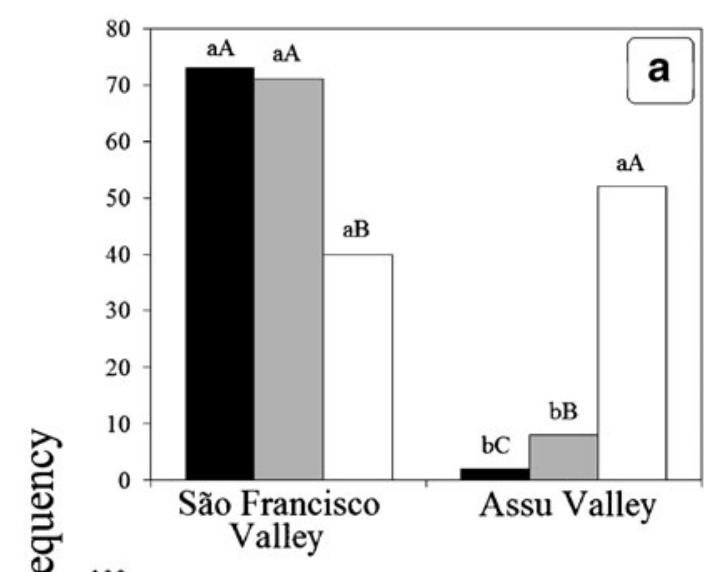

Neofusicoccum parvum

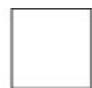

Lasiodiplodia theobromae

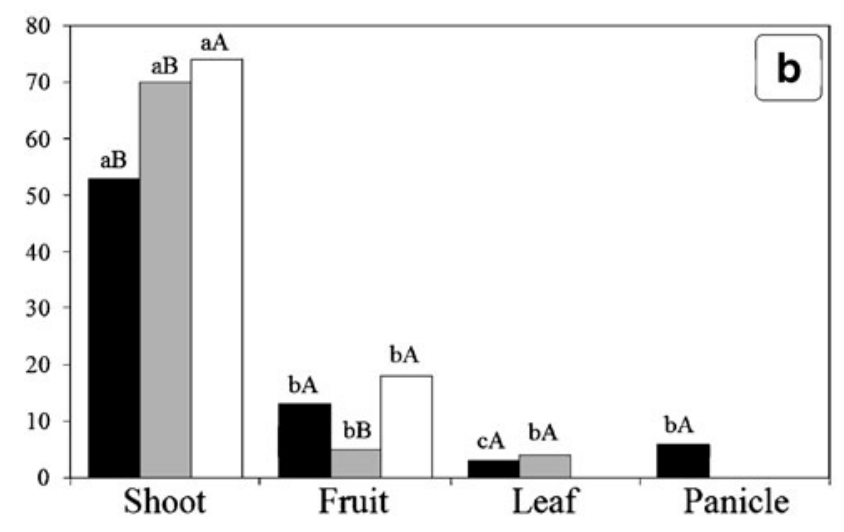

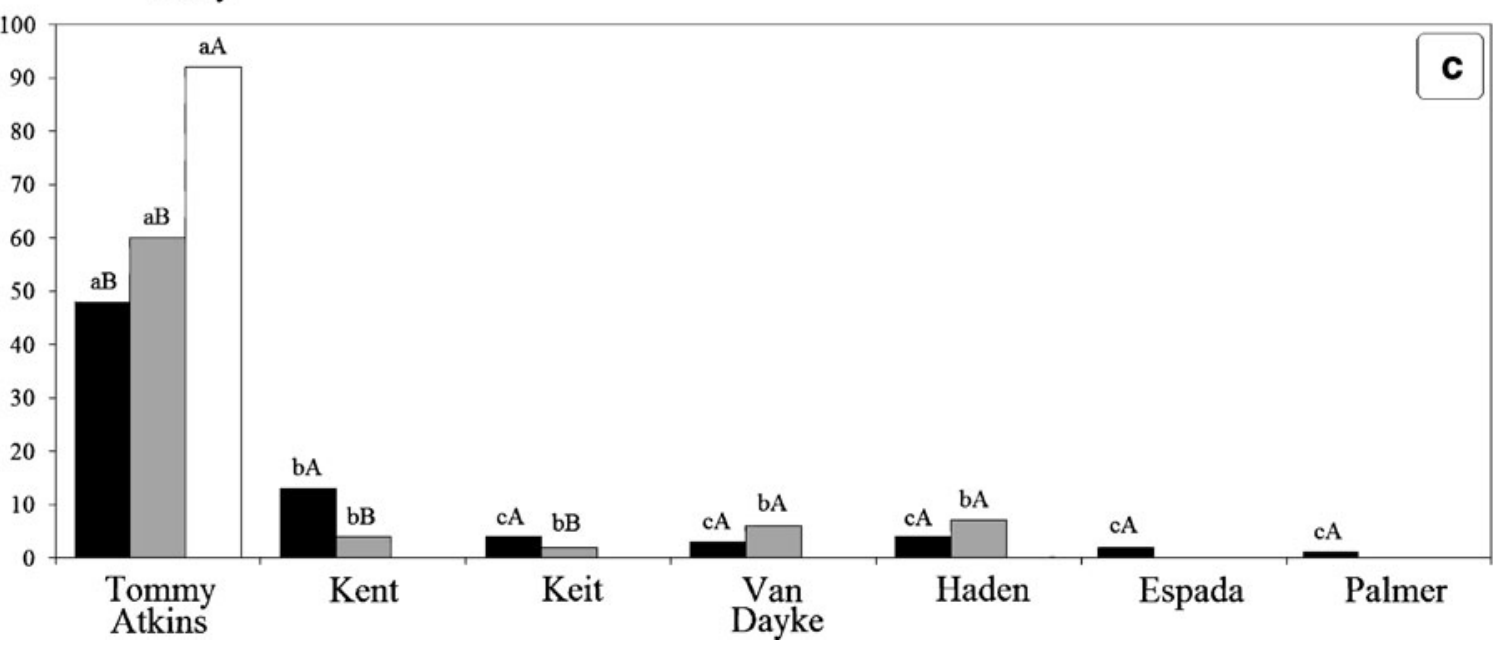

Fig. 3 Frequency of association of Botryosphaeriaceae species with mango tissue samples exhibiting symptoms of dieback/ peduncle rot per: a region; b part of the plant; and c cultivar. Bars with same uppercase letter do not differ between one another $\left(\chi^{2} ; P=0.05\right)$ within region, part of the plant or variety. Bars of same colour with same lowercase letter do not differ between one another $\left(\chi^{2} ; P=0.05\right)$ 
Fig. 4 Single tree resulting from Maximum Likelihood analysis generated from internal transcribed spacer (ITS) sequences from species of Botryosphaeriaceae. Bootstrap values are indicated as Maximum parsimony/Maximum likelihood at each node. Bootstrap values less than $50 \%$ are not shown

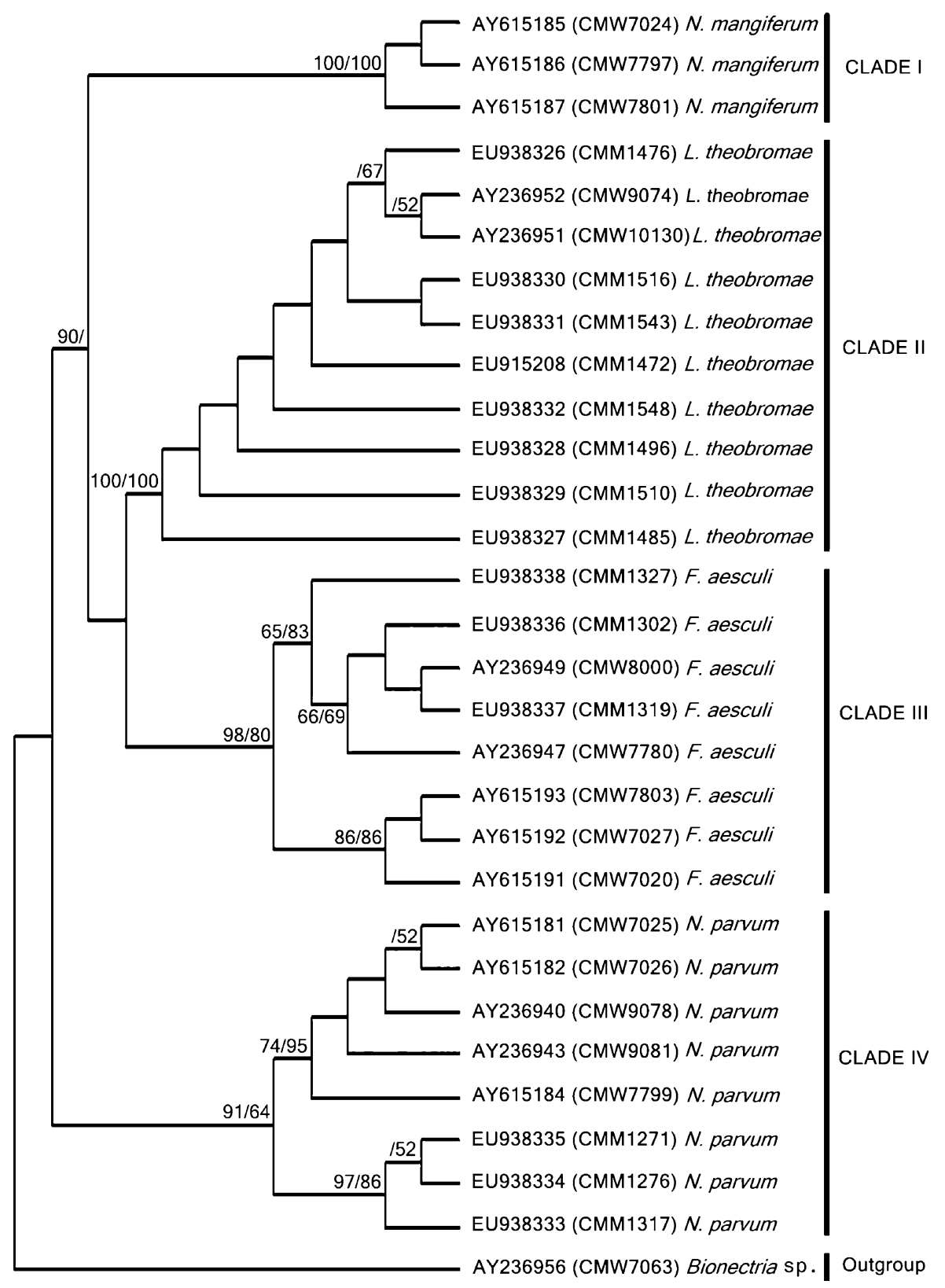

shown). The only differences between the data analysis methods were changes in the positions of some isolates within each clade.

Pathogenicity and virulence tests

Although all isolates of $L$. theobromae were pathogenic, $13 \%$ of the isolates of $F$. aesculi and $7.6 \%$ of the isolates of $N$. parvum were nonpathogenic (data not shown). There were significant $(P=0.05)$ differences in virulence among the species, wherein $L$. theobromae was most virulent and $N$. parvum was more virulent than $F$. aesculi (Fig. 5). Minor, but significant, differences in virulence also occurred among some of the isolates of $L$. theobromae (Fig. 5).

\section{Discussion}

The present study is the first survey of species of the Botryosphaeriaceae that are associated with tip dieback and stem-end rot in mango in the semiarid 
Fig. 5 Mean lesion diameter $(\mathrm{mm}) 72 \mathrm{~h}$ after inoculation of isolates from three species of Botryosphaeriaceae in mango fruit. Mean values followed by the same letter do not differ between one another (Mann-Whitney; $P=0.05$ ). Vertical lines represent the standard error of the means

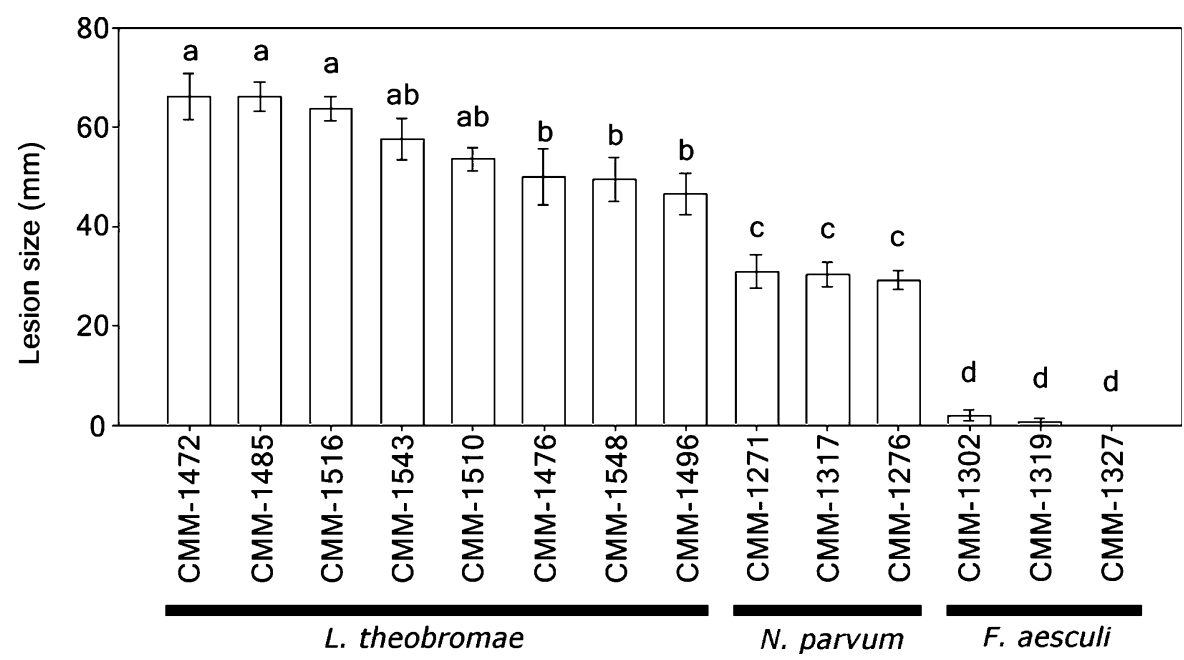

region of northeastern Brazil. Three species of Botryosphaeriaceae were identified, L. theobromae, $F$. aesculi and $N$. parvum, based on morphometric characteristics and analyses of ITS sequences. Based on the virulence demonstrated by isolates of $F$. aesculi and N. parvum in the present work, it is unlikely that their presence would explain the recent increase in tip dieback intensity in commercial orchards. To elucidate this, further studies addressing the epidemiology and the establishment of control strategies should be conducted.

The characteristic, striate conidia of $L$. theobromae enable relatively easy identification of this species. Additionally, the presence of septum-free paraphases allows $L$. theobromae to be distinguished from other Lasiodiplodia spp. (Burgess et al. 2006). F. aesculi and $N$. parvum were less distinct, due to their overlapping conidial shapes and colours. However, there were more distinct differences in conidium $\mathrm{L} / \mathrm{W}$ ratios, which ranged from 1.24 to 1.4 for $F$. aesculi and was 2.4 for $N$. parvum (Table 2).

The phylogenetic analyses confirmed the morphometric identifications. As reported in previous studies (Slippers et al. 2004, 2005), isolates of L. theobromae, F. aesculi and $N$. parvum formed distinct clades. Their presence on different cultivars and mango organs and induction of symptoms on artificially inoculated fruit indicate that they are associated with mango diseases in the northeast region. F. aesculi and $N$. parvum are reported for the first time on mango in Brazil. Both species have been reported in other mango-producing regions of the world, and cause different symptoms with varying severities (Ploetz et al. 1996; Ramos et al. 1991; Khanzada et al. 2004). This raises the plausible question as to whether they are responsible for the important increase in dieback in mango trees in Brazil, which has been attributed to only L. theobromae (Freire et al. 2004; Tavares 2002; Tavares et al. 1991). However, due to the results obtained by inoculation on fruits, more studies are needed to investigate this possibility.

Others have examined the pathogenicity and virulence of species of Botryosphaeriaceae on mango (Khanzada et al. 2004; Ploetz et al. 1996; Ramos et al. 1991). For example, in studies carried out with seedlings inoculated with isolates originating from Florida (USA), B. ribis was found to be five-fold more effective in causing dieback than L. theobromae (Ramos et al. 1991). In Australia, the most common pathogen is $N$. parvum, which apparently causes huge losses (Slippers et al. 2005). F. aesculi and N. parvum predominate in the São Francisco Valley from which most reports of severe disease come (Tavares 2002; Tavares et al. 1991). In contrast, $84 \%$ of the isolates obtained from the Assú Valley were L. theobromae (Fig. 1). Although L. theobromae was most virulent on fruit, it and the other species were not tested on other mango organs in this study. Thus, additional work is needed to evaluate the importance of these species as causal agents of dieback in the study areas.

Differential susceptibility of the host cultivars does not explain the distribution of the species between the regions. The isolates analyzed were obtained from seven cultivars; in the Assú Valley, all the sampled orchards were planted with 'Tommy Atkins'. The association of $L$. theobromae was only found in trees 
of this cultivar, which may lead to the association of the low frequency of this species in the São Francisco Valley because of no sampling was done in orchards planted with other cultivars. However, taking into consideration only the isolates obtained from 'Tommy Atkins' in both regions, the prevalence of $L$. theobromae in the São Francisco Valley was low, with a frequency of association of $38 \%, 33 \%$ and $29 \%$ for $F$. aesculi, N. parvum and $L$. theobromae, respectively (data not shown). Another relevant factor is that 'Tommy Atkins' is widely grown in both regions, which makes one consider whether the distribution data in the present study is representative of what occurs in the field.

The present study revealed the association of three species of Botryosphaeriaceae (L. theobromae, F. aesculi and $N$. parvum) associated with mango trees and fruit with symptoms of dieback and stem-end rot in the semi-arid region of northeastern Brazil. The distribution of the species differed between the two sampling regions, with $F$. aesculi and $N$. parvum predominant in the São Francisco Valley, whereas $L$. theobromae predominated in the Assú Valley. Although all three species were capable of causing peduncle rot in mangos, the degree of intensity of the symptoms varied between species as well as between isolates of a species. Considering the possibility that $F$. aesculi and $N$. parvum may be endophytic in mango trees in field conditions, a further series of studies will be conducted.

Acknowledgments We thank Dr. Mary Palm-Hernandez and Dr. Nicholle O'Neill for critical review of the manuscript. The authors are also thankful for funding provided by the Conselho Nacional de Desenvolvimento Científico e Tecnológico (CNPq $\left.\mathrm{n}^{\mathrm{o}} 470638 / 2008-7 ; 35.0287 / 2008-2\right)$ and by the Fundação de Ámparo à Ciência e Tecnologia do Estado de Pernambuco (FACEPE n ${ }^{\circ}$ DCR-0066-5.01/08; APQ-0061-5.01/08).

\section{References}

Al Adawi, A. O., Deadman, M. L., Al Rawahi, A. K., Khan, A. J., \& Al Maqbali, Y. M. (2003). Diplodia theobromae associated with sudden decline of mango in the Sultanate of Oman. Plant Pathology, 52, 419.

Batista, A. C. (1947). Mal do Recife, grave doença da mangueira. Recife-PE, Brasil: Escola Superior de Agricultura de Pernambuco.

Burgess, T. I., Barber, P. A., Mohali, S., Pegg, G., Beer, W., \& Wingfield, M. J. (2006). Three new Lasiodiplodia spp. from the tropics, recognized based on DNA sequence comparisons and morphology. Mycologia, 98, 423-435.

Crous, P. W., Slippers, B., Wingfield, M. J., Rheeder, J., Marasas, W. F. O., Philips, A. J. L., et al. (2006). Phylogenetic lineages in the Botryosphaeriaceae. Studies in Mycology, 55, 235-253.

Denman, S., Crous, P. W., Taylor, J. E., Kang, J. C., Pascoc, I., \& Wingfield, M. J. (2000). An overview of the taxonomic history of Botryosphaeria, and a re-evaluation of its anamorphs based on morphology and ITS rDNA phylogeny. Studies in Mycology, 45, 129-140.

Freire, F. C. O., Viana, F. M. P., Cardoso, J. E., \& Santos, A. A. (2004). Novos hospedeiros do fungo Lasiodiplodia theobromae no Estado do Ceará-Comunicado Técnico. Fortaleza-CE, Brazil: EMBRAPA.

Javier-Alva, J., Gramaje, D., Alvarez, L. A., \& Armengol, J. (2009). First report of Neofusicoccum parvum associated with dieback of mango trees in Peru. Plant Disease, 93, 426.

Khanzada, M. A., Lodhi, A. M., \& Shahzad, S. (2004). Pathogenicity of Lasiodiplodia theobromae and Fusarium solani on mango. Pakistan Journal of Botany, 36, 181189.

Khanzada, M. A., Lodhi, A. M., \& Shahzad, S. (2005). Chemical control of Lasiodiplodia theobromae, the causal agent of mango decline in Sidh. Pakistan Journal of Botany, 37, 1023-1030.

Ma, Z., \& Michailides, T. J. (2002). Characterization of Botryosphaeria dothidea isolates collected from pistachio and other plant hosts in California. Phytopathology, 92, 519-526.

Ma, Z., Boehm, E. W. A., Luo, Y., \& Michailides, T. J. (2001). Population structure of Botryosphaeria dothidea from pistachio and other hosts in California. Phytopathology, 91, 665-672.

Mendes, M. A. S., Silva, V. L., Dianese, J. C., Ferreira, M. A. S. V., Santos, C. E. N., Neto, E. G., et al. (1998). Fungos em Plantas no Brasil. Brasília-DF, Brazil: EMBRAPA.

Murray, M. G., \& Thompson, W. F. (1980). Rapid isolation of high molecular weight DNA. Nucleic Acids Research, 8, 4321-4325.

Niekerk, J. M., Crous, P. W., Fourie, P. H., \& Halleen, F. (2004). DNA phylogeny, morphology and pathogenicity of Botryosphaeria species on grapevines. Mycologia, 96, 781-798.

Nogueira, E. M. C., Ferrari, J. T., \& Louzeiro, L. M. (2001). Ocorrência de Lasiodiplodia theobromae causando perdas severas de frutos em mangueira no Estado de São Paulo. Arquivos do Instituto Biológico, 68, S53.

Pereira, A. L., Silva, G. S., \& Ribeiro, V. Q. (2006). Caracterização fisiológica, cultural e patogênica de diferentes isolados de Lasiodiplodia theobromae. Fitopatologia Brasileira, 31, 572-578.

Ploetz, R. C., Benscher, D., Vázquez, A., Colls, A., Nagel, J., $\&$ Schaffer, B. (1996). A reexamination of mango decline in Florida. Plant Disease, 80, 664-668.

Posada, D., \& Crandall, K. A. (1998). MODELTEST: testing the model of DNA substitution. Bioinformatics, 14, 817-818.

Ramos, L. J., Lara, P. S., McMillan, R. T., \& Narayanan, K. R. (1991). Tip dieback of mango (Mangifera indica) caused by Botryosphaeria ribis. Plant Disease, 75, 315-318. 
Ramos, L. J., Davenport, T. L., McMillan, R. T., \& Lara, P. (1997). The resistance of mango (Mangifera indica) cultivars to tip dieback disease in Florida. Plant Disease, $81,509-514$.

Ribeiro, I. J. A. (1997). Doenças da mangueira. In H. Kimati, L. Amorim, A. Bergamin Filho, L. E. A. Camargo, \& J. A. M. Rezende (Eds.), Manual de Fitopatologia: Doenças das Plantas Cultivadas (pp. 511-524). São Paulo-SP, Brazil: Agronômica Ceres.

Slippers, B., Crous, P. W., Denman, S., Coutinho, T. A., Wingfield, B. D., \& Wingfield, M. J. (2004). Combined multiple gene genealogies and phenotypic characters differentiate several species previously identified as Botryosphaeria dothidea. Mycologia, 96, 83-101.

Slippers, B., Johnson, G. I., \& Crous, P. W. (2005). Phylogenetic and morphological reevaluation of the Botryosphaeria species causing diseases of Mangifera indica. Mycologia, 97, 99-110.

Souza, J. S., Almeida, C. O., Araújo, J. L. P., \& Cardoso, C. E. L. (2002). A cultura da mangueira. In P. J. C. Genú \& C. A. Q. Pinto (Eds.), EMBRAPA Informação Tecnológica (pp. 19-30). Brasília-DF, Brazil: EMBRAPA.
Tavares, S. C. C. H. (2002). Epidemiologia e manejo integrado de Botryodiplodia theobromae - Situação atual no Brasil e no mundo. Fitopatologia Brasileira, 27, 46-52.

Tavares, S. C. C. H., Menezes, M., \& Choudhury, M. M. (1991). Infecção da mangueira por Botryodiplodia theobromae Lat. na região semi-árida de Pernambuco. Revista Brasileira de Fruticultura, 13, 163-166.

Thompson, J. D., Higgins, D. G., \& Gibson, T. J. (1994). Clustal W: improving the sensitivity of progressive multiple sequence alignment through sequence weighting, position-specific gap penalties and weight matrix choice. Nucleic Acids Research, 22, 4673-4680.

White, T. J., Bruns, T. D., Lee, S., \& Taylor, J. W. (1990). Amplification and direct sequencing of fungal ribosomal RNA genes for phylogenetics. In M. A. Innis, D. H. Gelfand, J. J. Sninsky, \& T. J. White (Eds.), PCR protocols: a guide to methods and applications (pp. 315-322). New York: Academic.

Zwick1, D. J. (2006). Genetic algorithm application for the phylogenetic analyses of large biological sequence datasets under maximum likelihood. Ph. D. thesis. University of Texas at Austin. 